\title{
KARAKTERISTIK VISUAL BANGUNAN PASCA KERUSUHAN MEI 98 SEBAGAI PEMBENTUK WAJAH KOTA SURAKARTA
}

Bangkit Adhi Wicaksono

Program Studi Arsitektur Fakultas Teknik Universitas Muhammadiyah Surakarta e-mail: bangkitadhi89@gmail.com

\section{Dyah Widi Astuti}

Program Studi Arsitektur Fakultas Teknik Universitas Muhammadiyah Surakarta e-mail: dyahwidi.dw@gmail.com

\begin{abstract}
ABSTRAK
Era pergantian Orde Baru menuju Era Reformasi yang terjadi di Indonesia menyebabkan berbagai kerusuhan. Surakarta merupakan salah satu kota yang mengalami kerusuhan. Banyak massa yang melakukan aksi kerusuhan yang berdampak pada kerusakan bangunan di Kota Surakarta. Banyak kerugian yang terjadi. Pasca kerusuhan bangunan mulai direnovasi, namun hal ini mengakibatkan tampilan visual bangunan telah berubah. Penelitian ini bertujuan mencari perbedaan visual sebelum dan sesudah kerusuhan, faktor pengaruhnya, dan pengaruh perubahan terhadap wajah Kota Surakarta. Metode yang dipilih adalah metode komparasi dengan membandingkan data tahun 1998 dengan 2019. Terdapat tujuh sampel bangunan yang dianggap mewakili citra tampilan wajah Kota Surakarta. Hasil penelitian ini menunjukan indikator yang berubah dari ketujuh sampel bangunan tersebut yaitu : garis, bentuk, dan irama. Faktor yang mempengaruhi perubahan tersebut adalah rasa keamanan yang kurang sehingga mengakibatkan para penduduk merenovasi bangunan yang rusak. Keadaan ini mengakibatkan perubahan fasad bangunan menjadi lebih tertutup, kuat, dan aman. Hal ini mempengaruhi tampilan bangunan sehingga memicu terbentuknya wajah Kota Surakarta yang kaku dan kokoh.
\end{abstract}

KATA KUNCI : visual, kerusuhan Mei 98, wajah Kota Surakarta

\section{PENDAHULUAN}

Kota Surakarta merupakan kota di bagian selatan Pulau Jawa. Kota ini diapit oleh empat kebupaten yaitu Boyolali, Sukoharjo, Sragen, dan Karanganyar. Surakarta telah mengalami berbagai macam peristiwa yang menjadi tonggak sejarah, salah satu yang dikenal adalah kerusuhan Mei 98. Awal mula terjadi kerusuhan disebabkan oleh krisis moneter yang dialami oleh masyarakat Indonesia. Masyarakat menuntut dilakukannya reformasi. Hal ini memicu terjadinya kerusuhan. Bulan Mei 1998 merupakan puncak terjadinya kerusuhan. Cukup banyak bangunan yang terdampak kerusuhan, seperti supermarket, dealer, pertokoan, hotel, bank, restoran, pemukiman, bioskop, teater, dan fasilitas lainnya. Bangunan - bangunan tersebut dibakar oleh massa. Kerugian material mencapai miliaran rupiah (Noegroho, 1998).

Penelitian ini berkaitan dengan wajah Kota Surakarta yang mengalami peristiwa Mei 98. Reformasi 1998 merupakan situasi yang krisis. Krisis 12-13 Mei 1998 merupakan situasi yang mengakibatkan efek trauma pada masyarakat. Kerusuhan berupa pembakaran bangunan public maupun private di pusat kota Solo (Noegroho, 1998), sekaligus penjarahan, yang dipicu oleh protes rakyat terhadap kebijakan pada masa orde baru yaitu diskriminasi terhadap etnis Tionghoa (Wibowo, 2010). Pasca kerusuhan, satu per satu bangunan dibangun dan kembali beroperasi normal. Beberapa bangunan baru di Kota Surakarta memiliki karakter yang beraneka ragam dari segi garis, warna, bentuk, irama, tekstur, proporsi, dan skala. Hal tersebut menciptakan keunikan tersendiri dibandingkan dengan daerah lain. Penelitian ini bertujuan mencari perbedaan visual sebelum dan sesudah kerusuhan, serta faktor-faktor pengaruhnya, dan bagaimana pengaruhnya terhadap wajah Kota Surakarta.

Visual merupakan sesuatu yang didasarkan pada penglihatan (Normies dalam Sudarwani, 2010). Karakter visual diciptakan dari bentukan fisik yang ada (Smardon dalam Puspitasari, 2013). Elemenelemen seperti garis, proporsi, warna, bentuk, skala, dan irama dapat membentuk karakter visual. Elemen pembentuk karakter visual diantaranya :

1. Garis

Garis merupakan sebuah tanda yang membedakan warna, bentuk, dan tekstur pada bangunan.

2. Proporsi

Proporsi merupakan suatu ikatan antar bangunan yang menciptakan keteraturan.

3. Warna

Warna merupakan sesuatu yang membedakan lingkungan dengan fasad bangunan. 
4. Bentuk

Bentuk merupakan suatu yang terbentuk dari beberapa elemen-elemen bangunan.

5. Skala

Skala merupakan suatu ukuran lingkungan dengan proporsi bangunan.

6. Irama

Irama merupakan garis, warna, bentuk, maupun potongan yang berulang dan teratur.

Beberapa unsur pembentuk bangunan (D.K.

Ching dalam Arifin, 2015) yaitu :

1. Wujud

Wujud merupakan hasil yang tercipta dari permukaan suatu bentuk. Garis itu merupakan wujud dimensi pertama dari penggabungan titik-titik.

2. Warna

Warna merupakan elemen yang membedakan suatu bentuk dengan lainnya. Warna akan memberikan karakter dan stabilitas visual pada sebuah bangunan.

3. Orientasi

Orientasi merupakan posisi suatu bentuk terhadap pandangan mata, bidang dasar, maupun arah mata angin. Orientasi terbuat pada wajah utama bidang vertikal.

4. Tekstur

Tekstur merupakan ciri permukaan suatu benda. Tekstur dapat mempengaruhi visual bangunan dan refleksi cahaya.

5. Irama

Irama merupakan pola yang ada atau terjadi di bagian depan bangunan. Elemen sekunder bisa membuat irama dalam komposisi.

6. Skala

Skala merupakan perbandingan ukuran relatifnya dengan bangunan sekitarnya.

7. Proporsi dan Dimensi

Dimensi merupakan ukuran bangunan dan mempengaruhi proporsinya.

\section{Wajah Kota}

Wajah kota adalah wajah yang mencitrakan sebuah kota itu sendiri. Hal tersebut berguna bagi masyarakat untuk mengenal kota tersebut. Banyak elemen-elemen visual yang membentuknya. Elemen pembentuk kota diantaranya berupa bangunan, jalan, taman kota, jembatan, signage (Manurung, 2018).

Kevin Lynch telah mendefinisikan identitas kota yaitu:

".....identitas kota bukan dalam arti keserupaan suatu objek dengan yang lain, tetapi justru mengacu kepada makna individualitas yang mencerminkan perbedaannya dengan objek lain serta pengenalannya sebagai entitas tersendiri." (Lynch, 1960) ".....identitas kota adalah citra mental yang terbentuk dari ritme biologis tempat dan ruang tertentu yang mencerminkan waktu (sense of time), yang ditumbuhkan dari dalam secara mengakar oleh aktivitas sosial-ekonomi-budaya masyarakat kota itu sendiri." (Lynch, 1972)

\section{METODE PENELITIAN}

Penelitian ini menggunakan dua metode yaitu:

1. Dokumentasi

Yaitu metode dengan cara menganalisa dokumentasi dalam buku berupa foto-foto bangunan pasca kerusuhan terjadi.

2. Observasi

Yaitu metode dengan cara mengamati obyek bangunan dengan indra manusia dan mengetahui kondisi eksisting.

\section{Teknik Analisa Data}

Tedapat satu teknik yang dipilih untuk menganalisa data yaitu komparasi. Komparasi adalah metode dengan cara membandingkan data. Data yang digunakan adalah foto tahun 1998 dan 2019.

\section{Obyek Penelitian}

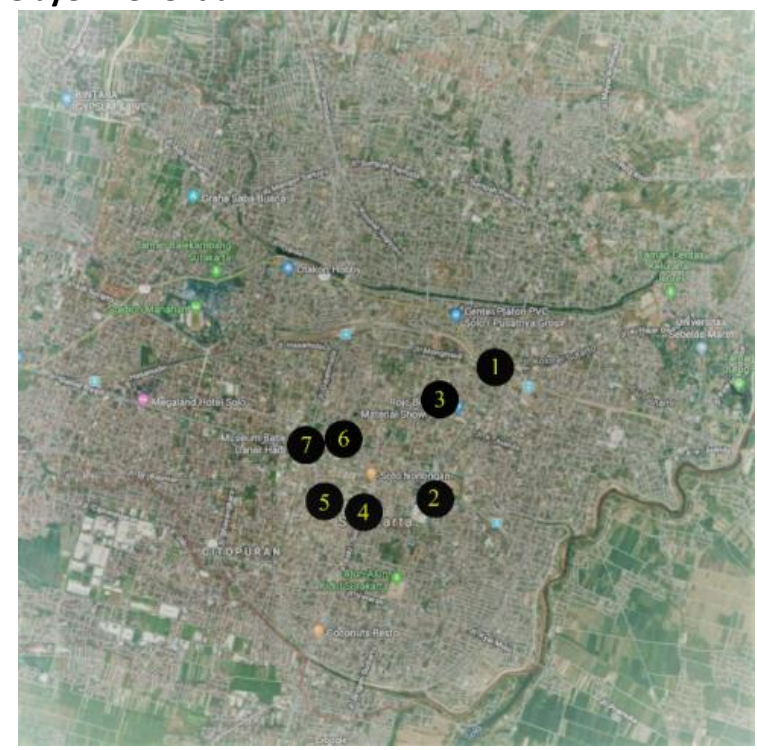

Gambar 1. Tujuh titik sampel bangunan yang dianggap mewakili citra tampilan wajah Kota Surakarta (sumber : Google Maps, 2019)

Tujuh sampel bangunan yang dianggap mewakili citra tampilan wajah Kota Surakarta (Gambar 1):

1. Hotel Asia

Hotel Asia Solo merupakan salah satu hotel berbintang tiga di bagian Solo Timur. Hotel ini terletak di Jl. Monginsidi No.1, Tegalharjo, Jebres, Surakarta.

2. BTC

BTC atau Beteng Trade Center merupakan pusat kawasan ekonomi di Kota Surakarta. Lokasinya 
sangat strategis berada di jantung kota, tepatnya di Jl. Mayor Sunaryo, Kedung Lumbu, Pasar Kliwon, Surakarta. Tempat ini digunakan untuk menjual pakaian.

3. Ratu Luwes

Ratu Luwes merupakan salah satu supermarket di Kota Surakarta. Supermarket ini terletak di JI. Letjen S. Parman No.32, Kestalan, Banjarsari, Surakarta.

4. Coyudan

Coyudan merupakan kawasan ekonomi berupa deretan toko dari timur ke barat di kedua sis jalan, yang menjual pakaian, peralatan rumah tangga, emas, sepatu, dan sebagainya. Kawasan ini terletak di sepanjang jalan Dr. Rajiman, Kemlayan, Kec. Serengan, Surakarta.

5. Matahari Singosaren

Matahari Singosaren merupakan pusat perbelanjaan modern di Kota Surakarta. Bangunan ini terletak di Jl. Gatot Subroto No. 27 - 28, Kemlayan, Serengan, Surakarta.

6. Bank Lippo/CIMB Niaga

Bank Lippo merupakan salah satu bank milik swasta. Bank ini telah berganti nama menjadi CIMB Niaga hingga sekarang. Bank ini terletak di Jl. Slamet Riyadi No.136, Timuran, Banjarsari, Surakarta.

7. Sami Luwes

Sami Luwes adalah bangunan supermarket yang berada di tengah kota. Supermarket ini terletak di Jl. Honggowongso No.2, Sriwedari, Laweyan, Surakarta.

\section{HASIL DAN PEMBAHASAN}

\section{Hotel Asia}

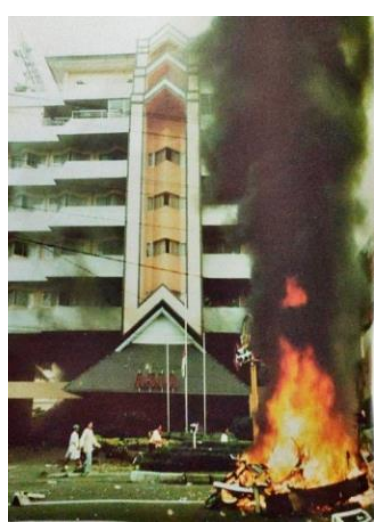

(a)

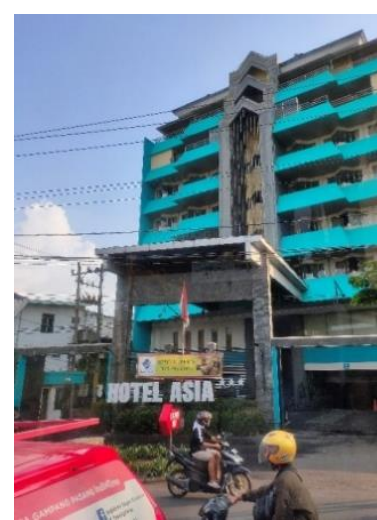

(b)
Gambar 2. Hotel Asia Tahun 1998 (a) dan tahun 2019 (b) (sumber : Noegroho, 1998; dokumentasi penulis,2019)

Perbandingan kondisi Hotel Asia di tahun 1998 saat terjadi kerusuhan, dengan kondisi tahun 2019 dapat dilihat dalam tabel 1 .
Tabel 1. Analisa Perbandingan Hotel Asia Tahun 1998 dengan 2019

\begin{tabular}{ll}
\hline Indikator & \multicolumn{1}{c}{ Analisa } \\
\hline Garis & $\begin{array}{l}\text { Garis telah berubah menjadi lebih indah } \\
\text { dan jelas yaitu hanya berupa } \\
\text { penambahan lampu dan pintu pagar besi. }\end{array}$ \\
\hline Bentuk & $\begin{array}{l}\text { Bentuk telah berubah menjadi kuat dan } \\
\text { kaku pada bagian depan hotel yaitu } \\
\text { berupa drop off yang modern dan pintu } \\
\text { pagar besi yang terkesan tertutup untuk } \\
\text { kewaspadaan. }\end{array}$ \\
\hline Warna & $\begin{array}{l}\text { Terjadi pergantian warna bagian depan } \\
\text { menjadi lebih damai dan menyejukan, } \\
\text { warna biru mendominasi tritisan. }\end{array}$ \\
\hline Orientasi & $\begin{array}{l}\text { Tidak terjadi perubahan orientasi hotel } \\
\text { (hotel tetap menghadap ke Jl. }\end{array}$ \\
\hline Monginsidi).
\end{tabular}

Sumber : Analisis penulis, 2019)

\section{Beteng Trade Center (BTC)}

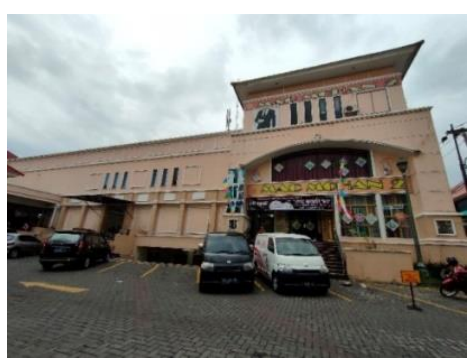

(a)

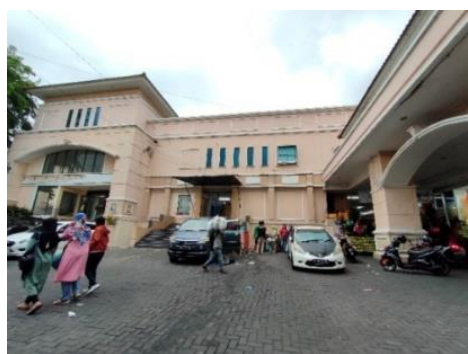

(b)

Gambar 3. Beteng Tahun 1998 (a) dan Tahun 2019 (b) (sumber : Noegroho, 1998; Dokumentasi penulis, 2019) 
Tabel 2. Analisa Perbandingan BTC Tahun 1998 dengan 2019

\begin{tabular}{|c|c|}
\hline Indikator & Analisa \\
\hline Garis & $\begin{array}{l}\text { Garis telah berubah dan membuat } \\
\text { bangunan lebih terkesan ramai, hal ini } \\
\text { dibuktikan dengan hasil pengamatan } \\
\text { yang menunjukan bagian fasad } \\
\text { mengalami penambahan corak, sirip, } \\
\text { maupun jendela vertikal. }\end{array}$ \\
\hline Bentuk & $\begin{array}{l}\text { Perubahan bentuk berupa penutupan } \\
\text { bagian luar yaitu hanya pergantian } \\
\text { jendela kaca dari yang besar menjadi } \\
\text { kecil dan berdinding beton karena } \\
\text { terjadi pembakaran. }\end{array}$ \\
\hline Warna & $\begin{array}{l}\text { Terjadi pergantian warna dari putih } \\
\text { menjadi cream. Hal ini membuat } \\
\text { bangunan terkesan hangat dan } \\
\text { menyenangkan. }\end{array}$ \\
\hline Orientasi & $\begin{array}{l}\text { Tidak terjadi perubahan orientasi } \\
\text { bangunan (bangunan tetap } \\
\text { menghadap ke Jl. Mayor Sunaryo). }\end{array}$ \\
\hline Tekstur & $\begin{array}{l}\text { Telah terjadi pergantian bagian fasad, } \\
\text { tekstur dari licin menjadi halus saja. }\end{array}$ \\
\hline Irama & $\begin{array}{l}\text { Terjadi pergantian irama yang } \\
\text { berulang pada dinding dari keramik } \\
\text { menjadi beton polos yang memiliki } \\
\text { sirip dan tritisan. }\end{array}$ \\
\hline Skala & $\begin{array}{l}\text { Skala bangunan mengalami } \\
\text { perubahan terdapat bangunan baru } \\
\text { yang mempengaruhi skala bangunan. }\end{array}$ \\
\hline $\begin{array}{l}\text { Proporsi dan } \\
\text { dimensi }\end{array}$ & $\begin{array}{l}\text { Bangunan masih digolongkan } \\
\text { bertingkat rendah dan proporsinya } \\
\text { tetap hanya kesan dari dingin menjadi } \\
\text { hangat }\end{array}$ \\
\hline
\end{tabular}

Sumber : (Analisis Penulis, 2019)

\section{Ratu Luwes}

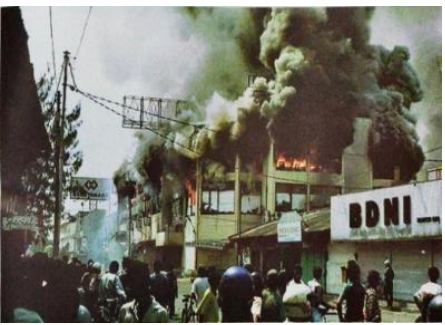

(a)

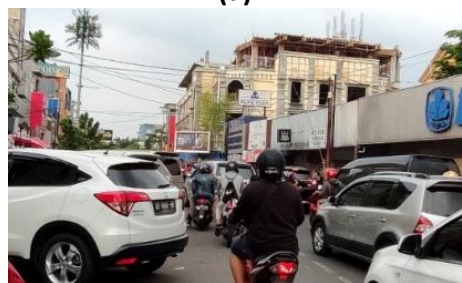

(b)

Gambar 5. Ratu Luwes Tahun 1998 (a) dan tahun 2019 (b)

(sumber : Noegroho, 1998, Dokumentasi Penulis, 2019)
Tabel 3. Analisa Perbandingan Ratu Luwes tahun 1998 dengan 2019

\begin{tabular}{|c|c|}
\hline Indikator & Analisa \\
\hline Garis & $\begin{array}{l}\text { Garis bangunan telah berubah lebih } \\
\text { kompleks dan ramai, hal ini } \\
\text { dibuktikan dengan penambahan } \\
\text { corak, sirip, maupun jendela } \\
\text { vertikal. }\end{array}$ \\
\hline Bentuk & $\begin{array}{l}\text { Perubahan bentuk menjadikan } \\
\text { bangunan lebih kokoh yaitu terjadi } \\
\text { pergantian jendela kaca dari yang } \\
\text { besar menjadi kecil dan berdinding } \\
\text { beton. }\end{array}$ \\
\hline Warna & $\begin{array}{l}\text { Warna bangunan tetap sama yaitu } \\
\text { cream. Hal ini membuat bangunan } \\
\text { terkesan hangat dan } \\
\text { menyenangkan. }\end{array}$ \\
\hline Orientasi & $\begin{array}{l}\text { Tidak terjadi perubahan orientasi } \\
\text { bangunan (bangunan tetap } \\
\text { menghadap ke Jl. Letjen S. } \\
\text { Parman). }\end{array}$ \\
\hline Tekstur & $\begin{array}{l}\text { Tekstur bangunan berubah lebih } \\
\text { timbul dan dinamis. }\end{array}$ \\
\hline Irama & $\begin{array}{l}\text { Terjadi penambahan irama yang } \\
\text { tegas dan kuat yaitu bagian sirip } \\
\text { dan corak persegi berulang pada } \\
\text { dinding dan kolom. }\end{array}$ \\
\hline Skala & $\begin{array}{l}\text { Bangunan telah bertambah } \\
\text { lantainya menjadi } 3 \text { dan terdapat } \\
\text { bangunan baru yang } \\
\text { mempengaruhi skala bangunan. }\end{array}$ \\
\hline $\begin{array}{l}\text { Proporsi dan } \\
\text { dimensi }\end{array}$ & $\begin{array}{l}\text { Bangunan masih digolongkan } \\
\text { bertingkat rendah dan proporsinya } \\
\text { tetap tidak ada perubahan. }\end{array}$ \\
\hline
\end{tabular}

\section{Coyudan}

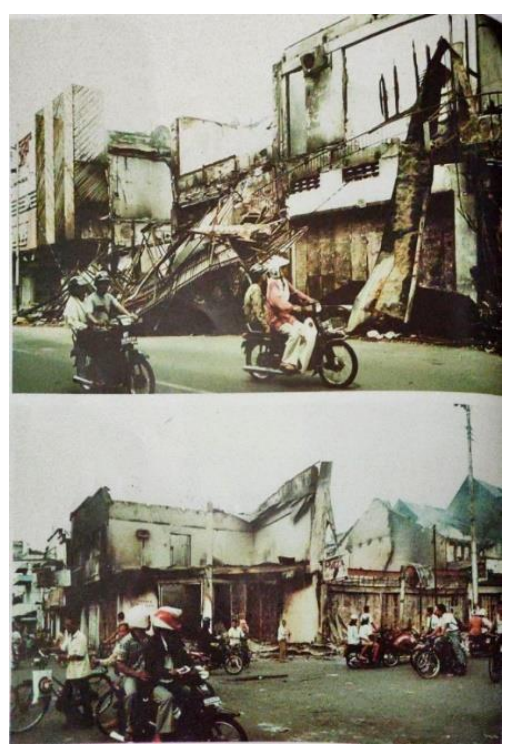

Gambar 6. Coyudan tahun 1998 (sumber : Noegroho, 1998) 
Coyudan termasuk kawasan paling parah mengalami kerusakan bangunan, sebagaimana gambar 6 , namun paling cepat kembali pulih. Pembangunan deretan pertokoan cepat dilakukan, mengingat kawasan ini merupakan pusat bisnis perekonomian kota. Gambar 7 memperlihatkan kondisi tahun 2019.

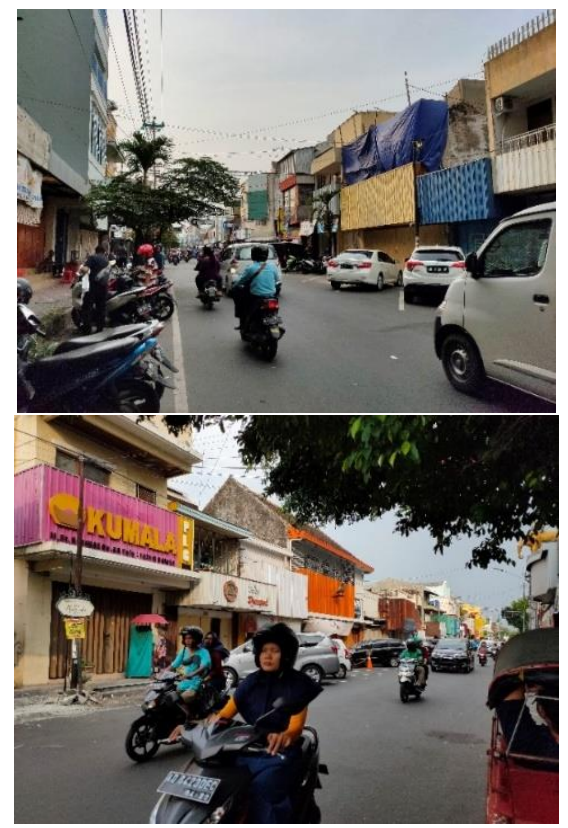

Gambar 7. Coyudan Tahun 2019

(sumber: Dokumentasi Penulis, 2019)

Tabel 4. Analisa Perbandingan Coyudan Tahun 1998 dengan 2019

\begin{tabular}{ll}
\hline \multicolumn{1}{c}{ Indikator } & \multicolumn{1}{c}{ Analisa } \\
\hline Garis & $\begin{array}{l}\text { Garis menjadi terlihat jelas. } \\
\text { Bangunan memunculkan garis } \\
\text { berupa teralis besi dan tritisan. }\end{array}$ \\
\hline \multirow{3}{*}{ Bentuk } & $\begin{array}{l}\text { Perubahan bentuk menjadi kuat dan } \\
\text { tegas terjadi pada penambahan } \\
\text { teralis besi pada bagian jendela dan } \\
\text { terkesan waspada maupun hati-hati. }\end{array}$ \\
\hline Warna & $\begin{array}{l}\text { Terjadi pergantian warna dari putih } \\
\text { ke warna-warni. Hal ini membuat } \\
\text { kawasan Coyudan terlihat menarik, } \\
\text { indah, dan menyenangkan. }\end{array}$ \\
\hline Orientasi & $\begin{array}{l}\text { Tidak terjadi perubahan orientasi } \\
\text { bangunan (bangunan tetap } \\
\text { menghadap ke Jl. DR. Radjiman). }\end{array}$ \\
\hline Tekstur & $\begin{array}{l}\text { Tekstur bangunan tidak terlihat } \\
\text { adanya perubahan, material tetap } \\
\text { halus dan licin. }\end{array}$ \\
\hline Irama & $\begin{array}{l}\text { Irama bangunan tidak ada } \\
\text { perubahan. }\end{array}$ \\
\hline Skala & $\begin{array}{l}\text { Skala bangunan tidak ada perubahan } \\
\text { sampai sekarang. }\end{array}$ \\
\hline dimensi & $\begin{array}{l}\text { Bangunan masih digolongkan } \\
\text { bertingkat rendah dan proporsinya } \\
\text { tetap tidak ada perubahan. }\end{array}$ \\
\hline
\end{tabular}

Sumber : (Analisis Penulis, 2019)

\section{Matahari Singosaren}

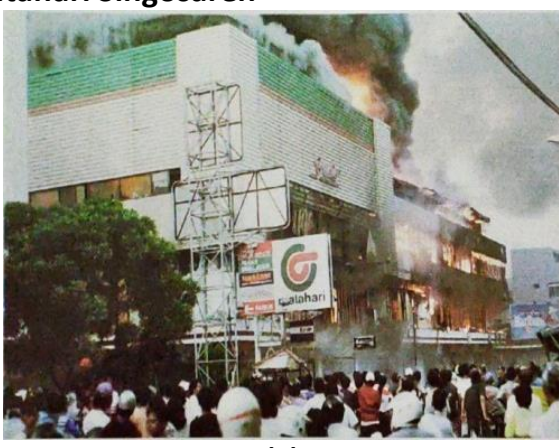

(a)

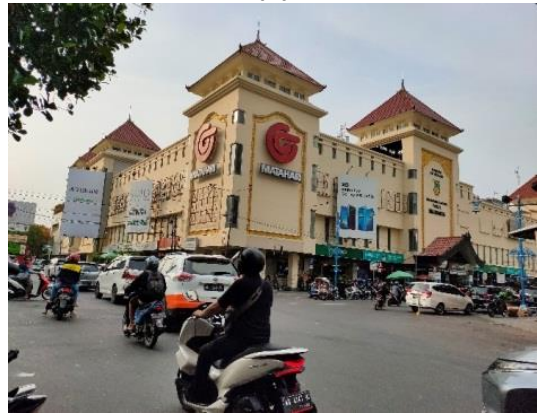

(b)

Gambar 8. Matahari Singosaren Tahun 1998 (a) dan Tahun 2019 (b)

(sumber : Noegroho, 1998, Dokumentasi Penulis, 2019)

Tabel 5. Analisa Perbandingan Matahari Singosaren Tahun 1998 dengan 2019

\begin{tabular}{|c|c|}
\hline Indikator & Analisa \\
\hline Garis & $\begin{array}{l}\text { Perubahan garis membuat bangunan } \\
\text { terlihat lebih ramai adalah dari } \\
\text { tritisan menjadi ornamen dan jendela } \\
\text { vertikal. }\end{array}$ \\
\hline Bentuk & $\begin{array}{l}\text { Bentuk telah berubah lebih kuat dan } \\
\text { aman daripada sebelumnya. Terjadi } \\
\text { pergantian fasad dari yang berjendela } \\
\text { besar ke hampir tanpa jendela yang } \\
\text { terkesan tertutup seakan trauma } \\
\text { pembakaran. }\end{array}$ \\
\hline Warna & $\begin{array}{l}\text { Terjadi pergantian warna dari putih } \\
\text { ke cream. Hal ini membuat bangunan } \\
\text { menjadi terkesan hangat dan } \\
\text { menyenangkan. }\end{array}$ \\
\hline Orientasi & $\begin{array}{l}\text { Tidak terjadi perubahan orientasi } \\
\text { bangunan (bangunan tetap } \\
\text { menghadap ke Jl. Gatot Subroto). }\end{array}$ \\
\hline Tekstur & $\begin{array}{l}\text { Tekstur bangunan berubah lebih } \\
\text { timbul dan dinamis. }\end{array}$ \\
\hline Irama & $\begin{array}{l}\text { Irama bangunan telah berubah } \\
\text { menjadi berulang dan simetris akibat } \\
\text { pembakaran dengan menghilangkan } \\
\text { tritisan diganti ornamen bangunan. }\end{array}$ \\
\hline Skala & $\begin{array}{l}\text { Skala bangunan mengalami } \\
\text { perubahan terdapat bangunan baru } \\
\text { yang mempengaruhi skala bangunan. }\end{array}$ \\
\hline
\end{tabular}

SINEKTIKA Jurnal Arsitektur, Volume 16 Nomor 2 Juli 2019 


\begin{tabular}{ll}
\hline \multicolumn{1}{c}{ Indikator } & \multicolumn{1}{c}{ Analisa } \\
\hline \hline $\begin{array}{l}\text { Proporsi dan } \\
\text { dimensi }\end{array}$ & $\begin{array}{l}\text { Bangunan masih digolongkan } \\
\text { bertingkat rendah dan proporsinya } \\
\text { berubah kesan dari dingin menjadi } \\
\text { hangat. }\end{array}$ \\
\hline \multicolumn{2}{c}{ Sumber : (Analisis Penulis, 2019) }
\end{tabular}

\section{Bank Lippo}

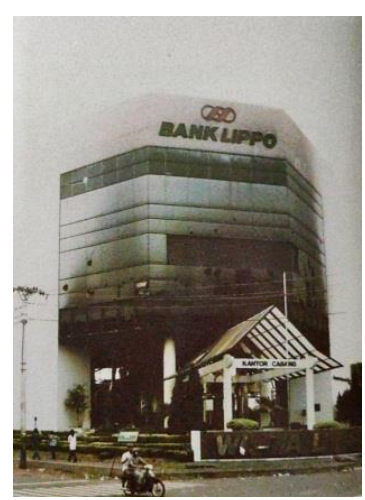

(a)

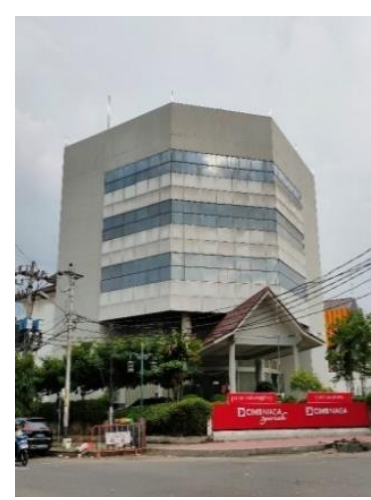

(b)
Gambar 9. Bank Lippo Tahun 1998 (a) dan tahun 2019 (b) (sumber : Noegroho, 1998; dokumen penulis, 2019)

Tabel 6. Analisa Perbandingan Bank Lippo Tahun 1998 dengan 2019

\begin{tabular}{|c|c|}
\hline Indikator & Analisa \\
\hline Garis & $\begin{array}{l}\text { Garis diganti lebih transparan. Bagian } \\
\text { fasad terjadi penambahan garis } \\
\text { horizontal berupa jendela kaca. }\end{array}$ \\
\hline Bentuk & $\begin{array}{l}\text { Bentuk telah berubah terutama } \\
\text { material menjadi kuat dan aman, hal ini } \\
\text { dibuktikan dengan pergantian drop off } \\
\text { dari transparan menjadi tertutup dan } \\
\text { dinding kaca tipis bagian hall diganti } \\
\text { balok kaca tebal. }\end{array}$ \\
\hline Warna & $\begin{array}{l}\text { Terjadi pergantian warna dari putih ke } \\
\text { abu-abu. Hal ini membuat bangunan } \\
\text { terkesan netral dan tentram. }\end{array}$ \\
\hline Orientasi & $\begin{array}{l}\text { Tidak terjadi perubahan orientasi } \\
\text { bangunan (bangunan tetap menghadap } \\
\text { ke Jl. Slamet Riyadi). }\end{array}$ \\
\hline Tekstur & $\begin{array}{l}\text { Tekstur bangunan tidak terlihat adanya } \\
\text { perubahan dan material tetap licin. }\end{array}$ \\
\hline Irama & $\begin{array}{l}\text { Irama bangunan telah ditambahi pada } \\
\text { bagian jendela yang berulang dan } \\
\text { simetris bagian fasadnya. }\end{array}$ \\
\hline Skala & $\begin{array}{l}\text { Skala bangunan tidak ada perubahan } \\
\text { sampai sekarang. }\end{array}$ \\
\hline $\begin{array}{l}\text { Proporsi dan } \\
\text { dimensi }\end{array}$ & $\begin{array}{l}\text { Bangunan masih digolongkan } \\
\text { bertingkat rendah dan proporsinya } \\
\text { bagus. }\end{array}$ \\
\hline
\end{tabular}

Sumber : (Analisis Penulis, 2019)

\section{Sami Luwes}

(a)

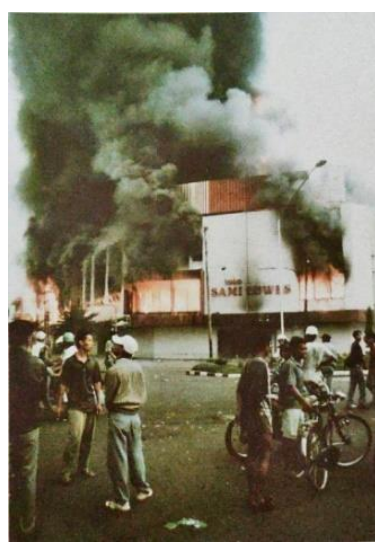

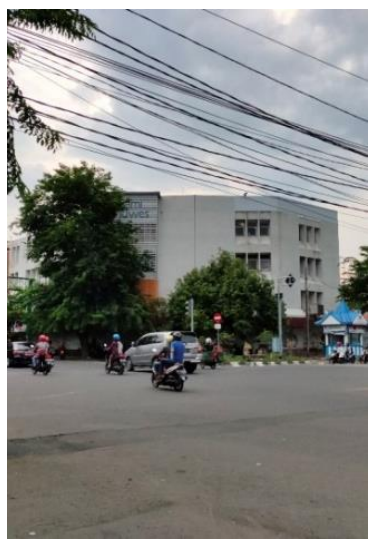

(b)
Gambar 10. Sami Luwes Tahun 1998 (a) dan tahun 2019 (b)

(sumber : Noegroho, 1998; dokumen penulis, 2019)

Tabel 7. Analisa Perbandingan Sami Luwes Tahun 1998 dengan 2019

\begin{tabular}{|c|c|}
\hline Indikator & Analisa \\
\hline Garis & $\begin{array}{l}\text { Garis terlihat kokoh dan kuat. } \\
\text { Penambahan teralis besi bagian fasad } \\
\text { untuk meningkatkan keamanan bagian } \\
\text { jendela maupun dinding. }\end{array}$ \\
\hline Bentuk & $\begin{array}{l}\text { Bentuk telah berubah menjadi gagah dan } \\
\text { kaku, hal ini dibuktikan dengan } \\
\text { pergantian jendela besar ke kecil dan } \\
\text { fasad diberi keramik dan teralis besi. }\end{array}$ \\
\hline Warna & $\begin{array}{l}\text { Terjadi pergantian warna dari putih } \\
\text { coklat ke putih. Hal ini membuat } \\
\text { bangunan terkesan steril dan bebas. }\end{array}$ \\
\hline Orientasi & $\begin{array}{l}\text { Tidak terjadi perubahan orientasi } \\
\text { bangunan (bangunan tetap menghadap } \\
\text { ke Jl. Honggowongso). }\end{array}$ \\
\hline Tekstur & $\begin{array}{l}\text { Tekstur bangunan tidak terlihat adanya } \\
\text { perubahan, material tetap licin. }\end{array}$ \\
\hline Irama & $\begin{array}{l}\text { Irama dibuat berulang dan simetris. } \\
\text { Irama yang berubah adalah bagian } \\
\text { jendela dan coraknya. Jendela diganti } \\
\text { menjadi kecil dan bercorak. }\end{array}$ \\
\hline Skala & $\begin{array}{l}\text { Sekarang sudah ada penambahan lantai } \\
\text { menjadi } 4 .\end{array}$ \\
\hline $\begin{array}{l}\text { Proporsi dan } \\
\text { dimensi }\end{array}$ & $\begin{array}{l}\text { Bangunan masih digolongkan bertingkat } \\
\text { rendah dan proporsinya bagus. }\end{array}$ \\
\hline
\end{tabular}

Sumber : (Analisis Penulis, 2019)

\section{KESIMPULAN DAN SARAN}

\section{Kesimpulan}

Hasil penelitian menunjukan bahwa indikator yang berubah dari ketujuh sampel bangunan tersebut adalah garis, bentuk, dan irama. Pertama, 
penambahan garis berupa teralis besi. Teralis bes digunakan untuk mengamankan bangunan pada bagian jendela kaca. Kedua, bentuk bukaan diperkecil dan diganti dengan dinding biasa. Hal ini meminimalisir serangan dari luar bangunan. Ketiga, irama berubah menjadi kuat dan aman sesuai dengan bagian yang rentan terhadap kerusuhan yang terjadi. Faktor yang mempengaruhi perubahan adalah rasa keamanan yang kurang sehingga mengakibatkan para penduduk merenovasi bangunan yang rusak. Hal ini berdampak pada material yang dipakai harus dapat melindungi bukaan-bukaan yang terdapat pada bangunan.

Kondisi ini mengakibatkan terjadinya perubahan fasad bangunan yang terkesan lebih tertutup, kuat, dan aman, sehingga mempengaruhi tampilan bangunan dan memicu terbentuknya wajah Kota Surakarta yang kaku dan kokoh.

\section{Saran}

Berikut merupakan saran yang diberikan, yaitu:

1. Bagi pemilik bangunan, diharapkan bisa merawat dan menjaga bangunan serta membuat tampilan yang lebih menarik karena bangunan tersebut bersejarah dan akan mempengaruhi wajah kota yang kuat dan kaku.

2. Bagi pemerintah daerah, diharapkan ada perhatian lebih kepada bangunan yang terdampak kerusuhan ini. Bangunan tersebut merupakan aset yang berharga bagi kota Surakarta. Bangunan tersebut harus dapat diselaraskan menjadi satu kesatuan yang harmonis.

\section{DAFTAR PUSTAKA}

(2019, Desember 11). Google. Retrieved from Google Maps: https://www.google.com/maps/@$7.5592086,110.8012596,10085 \mathrm{~m} /$ data $=! 3 \mathrm{~m} 1 ! 1 \mathrm{e}$ 3

Arifin, M. (2015). Karakteristik Fasad Rumah Minimalis di Surakarta. Sinektika: Jurnal Arsitektur, 52-61.

Ching, F. D. (1979). Arsitektur: Bentuk-Ruang dan Susunannya. Penerbit Erlangga.

Lynch, K. (1960). The Image of The City. Cambridge: The MIT Press.

Lynch, K. (1972). Good City Form. Cambridge: The MIT Press.

Manurung, P. (2018). Kota Untuk Semua: Ide Penataan Kota yang Komprehensif. Yogyakarta: Penerbit ANDI.

Noegroho, A. d. (1998). Rekaman Lensa Peristiwa Mei 1998 di Solo. Solo: PT. Aksara Solopos.
Puspitasari, A. W. (2013). Pengaruh Karakteristik Karya YB. Mangunwijaya Terhadap Karakter Visual Pemukiman Bantaran Sungai Studi Kasus: Kampung Code Utara, Yogyakarta. TEKNIK, 102108.

Sudarwani, M. (2010). Pengaruh Signage pada Bangunan-Bangunan Komersil Terhadap Estetika Visual Koridor (Doctoral dissertation, Thesis Universitas Diponegoro). 1-16.

Wibowo, I. d. (2010). Setelah Air Mata Kering: Masyarakat Tionghoa Pasca-Peristiwa Mei 1998. Jakarta: Penerbit Buku Kompas. 